\title{
Evaluation for Education Program and Basic Training for Jakarta Public Order Agency
}

\author{
Urkanus Sihombing \\ Universitas Negeri Jakarta \\ Email: urkanus1@yahoo.com \\ Hamidah \\ Universitas Negeri Jakarta \\ Email: hamidah@unj.ac.id \\ Billy Tunas \\ Universitas Negeri Jakarta \\ Email: tunas.billy@gmail.com
}

\begin{abstract}
This research/evaluation be held for evaluating Evaluation for education program and basic training for Jakarta public order agency in periode 2010 until 2018 which be held by Civil service police and Human Resources Development Agency (Field Study). This evaluation for analizing comprehensively to significant several aspect in several stages, which consists of stages1, including aspect : a. Legal foundation, b. Need analysis, c. Purpose, also program targets, and stages2, including aspect: $a$. Participant, $b$. Organization structure, $c$. Program and activities, d. Procedure, e.Guidebook, f. Instructors, g. Administrator/Committee, h. Instructional media, i. Means, infrastructure, and Budget, and stages3, including aspect, a. Participant reaction, $b$. Learning, c. Behavior, also stages4, which including: a.result, b. Program impact. Qualitative approach used on this research. Primary data, and secunder was obtained through observation, interview, study of document, focus group discussion, with all the credible informants.

This evaluation be held by using Stufflebeam model, Context, Input, Process and Product (CIPP). Data analysis trough interactive approach Miles and Huberman in data display activity, data reduction, and drawing conclusion. Research/evaluation result. Evaluation result showing that most aspects in contex stages, input, and process also product, getting good judgment, Which means it's done / available according to criteria, so program recommended need to be developed with adjustment on law No.23 of 2014 about local government and Government regulation No. 16 of 2018 about civil service police which has become the development guidelines of education basic program, technical, and functional civil service police all over Indonesia.
\end{abstract}

Keywords: performance management system, performance appraisal, appraisal error, performance management effectiveness, Electricity Authority of Cyprus.

Received: 18 August 2019 ;

Accepted: 22 January 2020 ;

Publish; June 2020. 


\section{How to Cite:}

Sihombing, U., Hamidah., \& Tunas, B. (2020). Evaluation for Education Program and Basic Training for Jakarta Public Order Agency. International Journal of Human Capital Management, 4 (1), 42-55. https://doi.org/10.21009/IJHCM.04.01.04

\section{INTRODUCTION}

A phenomenon which can be observed empirically about civil police service image,in civil perception tend not to be positive yet, and in many ways it is linked with eviction and conflict with street vendor, and demolition of illegal buildings. That condition become a challenge in their duty which have done by civil service police so the problems in government regulation/head government regulation their faced can be reduced or even removed, through communication approach which can educate member / community groups who is still actively committing government regulation/Head government regulation violations through the activities in public area which should be used for public interest. Effective, efficient, and productive duty implemention by civil service police may be filled with availability of human resources on civil service police, who are professional, humble, assertive, and humanist that government and the community can be wished. Civil service police members competencies are not only can fulfill the technical skills for doing only government regulation / head government regulation enforcement, but also must have soft skill competence in the form of public speaking skill, negotiation, persuasive approach so it can be effective in doing government regulation / head government regulation enforcement for creating public order, community tranquility, also community protection.

To preparing the figure of civil service police who is competent in handling government regulation / head government regulation problem , public order disorder, public peace, also public protection, government through ministry of home affairs establish one special education program for civil service police unit, namely the basic education, and training program civil service police that determined by regulation of the Minister of Home Affairs No.38 of 2010 about guidelines for providing basic education and training civil service police. The purpose of the civil service police basic education and training program, formulated in article 2 , i.e : a. Increasing knowledge, skills, attitude and behavior of civil service police, $b$. Increasing the professionalism of civil service police in implementing the duty of enforcing the government regulation, organization of public order, and public peace, also public protection, and c. Providing civil servant who has competence in accordance with the field of duty and requirements to be appointed as civil service police. Civil service police basic education and training program in Special Capital Territory of Jakarta has been carried out starting in the year 2012 until 2018.

The importance of evaluating the civil service police basic education and training program immediately because of the mandate of the legislation no. 23 of 2014 about regional regulation, and government regulation No.16 of 2018 about civil service police, for development civil service poloce education and training with technical and functional education and training. In this connection, the civil service police technical and functional education program implementation graduates will be directed to follow and pass the competency test also giving the certificate of competence. Certificate of competence for the civil service police members became one of the priority programs of the DKI Jakarta Provincial Human Resources Development Agency starting in 2018, and was carried out in collaboration with a unit that handled certification at the Ministry of Home Affairs Human Resources Development Agency.

The competency certificate is proof of one's competence related to knowledge, skills and behavioral attitudes in the field of civil service, and is one of the requirements for members of the Civil Police who will move positions from the executor, to become a civil service police functionary based on Government Regulation No. 4 of 2014 about the Civil Service Police Functional Position and Credit Score. Through this evaluation result accurate and complete information can be obtained as input reference for decision making for human resource 
development agency's ministry of home affairs who has main function and duty formulating education and training policies and programs civil service police.

\section{LITERATURE REVIEW}

This research using evaluation approach stufflebeam's model, with CIPP. According to Stufflebeam and Shinkfield in Wirawan (2011) states that "Evaluation is the process of delineating, obtaining, and providing descriptive and judgemental information about the worth and merit of some object's goals, design, implementation, and impact in order to guide decision making, serve needs for accountability, and promote understanding of the involved phenomena" which means that evalution is process of describe,obtain, and giving descriptive information, and an assessment of the value and benefits of the objectives, design, implementation, and impact of several objects to guide decision making, meet accountability needs, and developing understanding of certain phenomena, to obtain descriptive information about a program, a systematic process is carried out to assess the effectiveness or adequacy of something according to certain criteria and objectives.

As stated Wilbur Haris in Eko (2017): "Evaluation is the systematic process of judging the worth, desirability, effectiveness, or adequacy of something according to definitive criteria and purposes. The judgement is based upon a careful comparison of observation data with criteria standards". With understanding that the basic education and training program civil service police in one of evaluation object that will continued and developed with the new type of education and training in the form of technical and functional education and training In accordance with the mandate of the legislation no.23 of 2014 and government regulation no. 6 of 2018 about civil service police. Agus Sutiyono (2009) with dissertation title effects of Competency Based Education and Training or Competence Base Education And Training and working motivation on civil service police unit performance.

Experimental studies on civil service police's Special Capital Territory of Jakarta, conclude that : a. Performance of civil service police who given a training Competence Base Education And Training is higher than Civil Service Police Unit officers who were given conventional training, $\mathrm{b}$. There is an influence between training model with working motivation on civil service police performance and, c. Civil service police unit officer performance who were given training's model Competence Base Education And Training and having high work motivation, higher than Civil service police unit officer who were given conventional training and having high work motivation, also d. Civil service police performance who were given training's model Competence Base Education And Training and having low work motivation is higher than Civil service police unit officer performance who were given conventional training and having low work motivation.

Based on an understanding of the theory and the results of the research and policy, the application of the evaluation of the basic civil service police education and training program was compiled systematically in stages at the Context stage, which included aspects of: a. legal basis, b. needs analysis, c. purpose as well. program objectives, and Input stages, which include aspects of: a. Participants, b. Organizational Structure, c. Programs and Activities, d. Procedure, e. Guidebook, f. Teachers, g. Manager / Committee, h. Learning Media, i. Facilities, Infrastructure, and Budget, and Process, which includes aspects of: a. Participant's reaction, b. Learning, c. Behavior, as well as Product stages, which include: a. results and b. program impact. Evaluations were carried out on each stage and aspect of the basic civil service police education and training program.

The basic civil service police education and training program is an integral part of implementing the duties of regional heads to carry out enforcement of regional regulations and regional head regulations in order to create public order, community peace and protection of the people in the regions. In order to know the results and benefits of the Civil Service Police basic education and training program referred to, it is important to know a number of significant aspects that background and underlie the program at each stage, Context which includes: a. legal basis, needs analysis, program objectives and targets, and Input stages, which include: a. 
participants, b. curriculum, c. organizational structure, d. programs and activities, e. procedure, f. guidebook, g. teaching staff, h. manager / committee, i. learning media, j. means, k. infrastructure, and budget, and Process stages, which includes: aspects of reaction, learning and behavior of participants, as well as stages of the Product, which includes aspects: results and impacts on the external environment. Measuring the success of the achievement of the performance of the Provincial Civil Service Police Unit specifically for the capital city of Jakarta, in addition to improving internal performance of the Municipal Civil Service Police Unit specifically for the capital city of Jakarta, it is also related to the benefits and impact on reducing the number of violations of Regional Regulations and Regional Head Regulations, increasing regional income, and increasing public awareness to obey Regional Regulations / Regional Head Regulations.

\section{RESEARCH METHOD}

This research using qualitative approach. Creswell (2017) said that qualitative is method to explore and understand the meaning which is considered by a group of people to be social or humanitarian. Starting from that understanding, then the evaluation of basic Jakarta police order education and training program can be categorized relating to social problems faced by members of the civil service order in enforfing Government regulation/ Head government regulation, and organization of public order and public peace also public proventures also humanitarian issues are related to the efforts of certain community members to fulfill their daily needs through commercial ventures in street vendor and side the road near the shopping center or large trade center. Data collection is done through in document studies, systematic interview, and observation also limited group discussion.

Data collection for analising the suitability of the results of data collection with the evaluation criteria at each stage Context which includes: a. legal foundation, needs analysis, Program objectives and targets and Input stages, which include: a. participants, b. curriculum, c. organizational structure, d. programs and activities, e. procedure, f. guidebook, g. teacher, h. administrator/committee, i. learning media, j. means, k. infrastructure, and budget and Process stages, which including: aspects of reaction, learning and participant behavior, also process products, which including result and impact on external environment to interpret data is done with descriptive and qualitative analyst. Data analysis taken with the data display step, data reduction, and drawing conclusions

In evaluating the level of achievement of the results of the planning of each component and its aspects are each assessed from 0 to 100. Interpretation of research data / empirical data. Obtaining number for each stage and evaluation aspect adjusted to meet the criteria. Data that has been reduced and presented is then compared with evaluation criteria that has been set and expected goals (intens) with the interpretation that adapted from description of the assesment categories developed by Djaali and Puji Muljono (2008) based on meeting the evaluation criteria, starting from the category of assesment is less, enough, and good. Categorizing values is used as an interpretation of the level of availability, performance and achievement of each component and the aspects evaluated are presented according to the following stages:

Table 1 Rating Categories Based on Compliance Evaluation Criteria *)

\begin{tabular}{ccc}
\hline $\begin{array}{c}\text { Scoring } \\
\text { Scale }\end{array}$ & $\begin{array}{c}\text { Scoring } \\
\text { Category }\end{array}$ & Scoring Description \\
\hline 1 & Low & $\begin{array}{c}\text { Poor fulfillment: i.e. a small portion or not meeting at all according to the evaluation } \\
\text { criteria (meeting according to the criteria 0-34\%) }\end{array}$ \\
\hline 2 & Enough & $\begin{array}{c}\text { Sufficiently fulfilled: that is, some of the criteria meet according to the evaluation criteria } \\
\text { (meet according to the criteria of 35-67\%) }\end{array}$ \\
\hline 3 & Good & $\begin{array}{c}\text { Has been fulfilled: i.e. evaluan most or all of them have met in accordance with the } \\
\text { evaluation criteria (fulfilled according to the criteria } 68-100 \%)\end{array}$ \\
\hline
\end{tabular}

From evaluation result above can be explained that evaluation component included in the category of achievement level "Good" if the interpretation of data analysis results showed that 
most even all aspects evaluated according to evaluation criteria, the value is $68-100 \%$. evaluation component included in the category of achievement level "enough" if the interpretation of data analysis results showed that some aspects evaluated were carried out and some were not implemented according to the evaluation criteria, the value was 35-67\%. Evalution component included in the category of "Poor" performance and availability (achievement)if the interpretation of data from the analysis shows that less or little has been done / available according to the evaluation criteria, the value is $0-34 \%$.

\section{RESULT AND DISCUSSION}

Evaluation results of the basic education and training program for Jakarta public order agency according to the results of the study described data summarizes from the results of various data collection sources, analysis of compliance with evaluation criteria,assessment and decision as research findings at the Context stage, covering aspects: legal basis, needs analysis, program goals and objectives and Input stages, including aspect: a. Participant, b. Curriculum, c. Organization structure, d. Program and activities, d. Procedure, e. Guidebook, f. Tutors, g. Administrator/committee, h. learning media, i. means, j. infrastructure, and budget, and the stages of the Process, including aspects of the reaction, learning and behavior of participants, as well as at the Product stage, including aspects of the results and benefits of the program for Jakarta public order agency specifically the capital city of Jakarta and the external environment.

\section{a. Evaluation of contex stages}

1) Legal basis of the programs. According to evaluation result, there are various findings that basic education and training program for Jakarta agency order starting from 2012 until 2018, organized by the Jakarta agency order with Indonesian national army of Jakarta province and police, haven't fully utilized the basic education and training program civil service police because more material builds physical, mental and disciplinary competencies. Furthermore, in 2018, with the change in program organizers to be the Provincial Human Resources Development Agency specifically for the capital city of Jakarta, utilization of Regulation of the Minister of Home Affairs No.38 of 2010, and in accordance with the main tasks and functions of the Provincial Human Resources Development Agency, the special area of the capital city of Jakarta, has been fully implemented, or reached $100 \%$. However, with the change in policy regarding regional government from the beginning legislation No.32 of 2014 become legislation No.23 of 2014, also with government regulation No.6 of 2010 about civil service police replaced to government regulation no. 16 of 2018 about civil police service, then starting in 2019, the Human Resources Development Agency must comply with the provisions in the policy, including: development of educational and technical training programs and functional training of the Civil Service Police with different goals and objectives.

2) Requirements analysis of basic civil service police education and training programs. According to evaluation result of basic civil service police education and training programs implemented by Special Capital Territory of Jakarta government starting from 2012 until 2018 still prioritizing competency development needs for all the prospective civil servant With a pattern of 300 hours of study, and for the civil servants with a pattern of 150 hours of study. This condition has not yet balanced the needs of developing other human resource competencies in the Jakarta agency order who have structural positions echelon 4, echelon 3 and echelon 2 It is recommended to the Jakarta Provincial Human Resources Development Agency so that in the next program, propose basic education and training programs or technic or management enforcement of government regulation / head government regulation for every structural officer implemented by special capital city of Jakarta's civil service police. This need can strengthen the formation or composition of the team that will be assigned in enforcement government regulation / 
head government regulation to carry out public order, peace of society, and protection in all over the special capital city of Jakarta region.

3) Purpose

According to evaluation result achievement of the objectives of the civil service police education and training program. Not fully achieved. As specified in Regulation of the Minister of Home Affairs no.38 of 2010, the purpose is increasing the civil service knowledge and civil service attitude and behavior In reality, basic education and training programs from 2012 to 2018 provided more material to strengthen mental, physical and disciplinary abilities, while the analysis techniques for enforcing government regulation/head government regulations are not optimal. Furthermore, the results of the evaluation of the basic civil service police education and training program in 2018, materials related to effective communication, and negotiation skills have not been optimally provided. It is recommended that for the following year, material with negotiated technical content is improved.

4) Target

According to analysis result the programs target only for the pattern of 300 hours and 150 hours study, and not planning the pattern of 100 hours, 50 hours, and 35 hours study, and similarly in 2018, the Human Resources Development Agency has not yet prepared a program to develop the competencies of echelon 4, 3 and 2 officials. Considering the successful enforcement of Regional Regulation / Regional Head Regulation, it does not depend entirely on the competence of members of the Civil Service Police ,but also related to the support of regional apparatuses that compile and implement Regional Regulations and Regional Head Regulations, thats why the Human Resources Development Agency needs to add a new program for the Workshop handling the issue of Enforcement government regulation/head government regulation which presented participants from the Provincial Civil Service Police Unit. Municipal / Regency Civil Service Police Unit, District and Village Civil Service Police Unit to criticize the quality of public services. Thus, mapping problems and appropriate steps to solve institutionally supported by the program and budget will become guidelines for the Civil Service Police Unit and other relevant regional instruments.

\section{b) Input evaluation}

1) Participants of civil service police basic education and training

The findings in this research are that participants have met the requirements to attend basic civil service police of special capital city of Jakarta education and training with assessment 82,99 which mean good, most of the requirements have been met according to criteria. However, for increasing the quality of basic civil service police education and training programs in the future especially in the application of basic education and training to the new civil service police as mandated on Government regulation No.16 of 2018 about technical education and training, functional education and training and basic education and training, participant qualifications need to be reviewed, from the beginning only rank criteria / group and the proposed leadership and good behavior, updated with the formation of the Selection Team that examines psychological aspects, soft skills and mastery of information technology and hard skills comprehensively, so that only the best participants who can developed their potencial.

2) Curriculum

The findings in this research, that the education and training material most of them have met the criteria specified in the Regulations of ministry of home affairs No.38 of 2010 and its good to be developed with negotiation materi, public communication, public analysis and decision making

3) Organizational structure

Success criteria from input component on organizational structure aspect, there is a position within the organizational structure of the Human Resources Development 
Agency Special capital city of Jakarta has the duty of developing technical and functional competencies and forming a committee to organize basic Special capital city of Jakarta order agency education and training programs (based on criteria). Thus it can be concluded that from the aspect of the organizational structure of the management of the basic civil service education and training program the police is rated by $66.07 \%$ or by the category of Fair, which is partly in accordance with the criteria.

4) Programs and activities

Success criteria from input component on programs and activities aspect,has been included in the Annual Work Plan of the Provincial Human Resources Development Agency, the Jakarta Special Capital Region and Special capital city of Jakarta provincial budget (based on criteria). Therefore can be concluded that from the aspect of the programs and activities with the assessment $(82,84 \%)$ with good category which mean most of them have met the criteria.

5) Standards operational procedures

Success criteria from input component on asepcts of standard operational procedures the implementation of basic civil service police education and training programs as much as $50 \%$ which means low.

6) Tutors

Based on data collection between interview result and document studies compared with the existing evaluation criteria, it can be concluded that a total of 24 teaching staff or $100 \%$ have met the competency requirements in accordance with the criteria.

7) Guidebook

Based on data collection between interview result and document studies compared with the existing evaluation criteria, it can be concluded that committee has been providing and distributing a guidebook for the implementation of basic civil service police education and training programs, with different forms for participants and teaching staff or $100 \%$ has met according to the criteria.

8) Administrator /committee

Based on data collection between interview result and document studies compared with the existing evaluation criteria, it can be concluded that committee have provided very satisfying services to participants of basic education and training programs or $90.50 \%$ have met according to the criteria.

9) Instructional media

Based on document studies, known that The Head of Standardization and Quality Assurance Division has submitted the Evaluation Results of the Implementation of basic education and training through internal memo number 919/-084 dated may 7, 2018 addressed to the Head of the Division of Technical and Functional Competence, with the results of the level of satisfaction of the weighted average of the learning media of basic education and training programs as much as Class 3, very satisfying at $90.38 \%$.

10) Facilities

Success criteria input evaluation on facilities indicator is providing in total and quality according to the budget that provided. Based on data collection between interview result and document studies compared with the existing evaluation criteria, it can be concluded that the facilities are available and the benefits are stated to be very satisfying to participants of basic education and training programs or $90.38 \%$ have met the criteria.

11) Infrastructures

Success criteria for evaluation of inputs to the facility indicators are available in quantity and quality according to the available budget. Based on data collection between interview result and document studies compared with the existing evaluation criteria, it can be concluded that the infrastructures are available and the benefits are stated to be very satisfying to participants of basic education and training programs or $92.31 \%$ have met the criteria.

12) Budget 
Based on data collection between interview result and document studies compared with the existing evaluation criteria, it can be concluded that the assessment with a sufficient budget category (67\%), which means that not yet the needs of the basic civil service police education and training program are provided in the budget of the Special capital city of Jakarta Provincial Human Resources Development Agency in accordance with the criteria.

\section{Process evaluation}

Evaluation of the process of implementing basic education and training programs for the Provincial Civil Service Police in the special area of the capital city of Jakarta, including: a. preparation meeting, b. calling participants, c. Determination of Teaching Staff and Teaching Staff Assistant.d. implementation of learning and teaching according to a schedule consisting of: opening ceremony, implementation of learning and teaching, closing ceremony, Based on the evaluation result there are several findings in the process of implementing the Civil Service Police education and training program, with the following explanation:

Preparation meeting

Based on document studies, known that the committe has conducted a preparatory meeting by inviting several related parties, including the Head of the Ministry of Home Affairs Human Resources Development Agency, Head of the Technical and Functional Development Division, the Provincial Human Resources Development Agency specifically the capital city of Jakarta,Head of Satdarization and Quality Assurance Division of the Human Resources Development Agency of the Ministry of Home Affairs of the Province of special capital city of Jakarta and the Coordinator of Widyaiswara's Agency for the Development of Human Resources at the Ministry of Home Affairs in the Jakarta province through the letter number 538/084-2 Dated January, 29 2018, with agenda discussing curriculum and tutors.

The preparatory meeting result, agreed : implementing basic Jakarta public order agency 4 forces education and training each generation held for 17 days including saturday, sunday, and day off. Every day 12 hours of study 245 minutes at the Jakarta Islamic Center North Jakarta dormitory, tutors from the professional elements, elements of the central Jakarta metro area police, Indonesian National Armed Forces, Elements of the Ministry of Home Affairs Widyaiswara,Elements of the Department of Human Resources Development of the Ministry of Home Affairs of the Province of the Special Capital Region of Jakarta. c) according to Regulation of the Minister of Home Affairs no. 38 of 2010 concerning Guidelines for Providing basic civil service police education and training which will be used for basic civil education police training and training Pattern of 150 hours of study.

The material as follows, arranged in a schedule, e) To select participants who meet the requirements, a Selection Team with the Human Resources Development Agency of the Ministry of Home Affairs special region of Jakarta and Jakarta public order agency, and subsequently determined by Decree of the Head of the Provincial Human Resources Development Agency for the special area of the capital city of Jakarta as a candidate Participant.

\section{1) Calling participants}

For receiving direction from committee. Based of interview result with Head of Sub Division of Basic Services and Options, Special Capital Territory of Jakarta Provincial Human Resources Development Agency states that, to meet the statutory provisions that require it civil service police members attend the basic civil service police education and training and in accordance with the 2018 Provincial Human Resources Development Agency program in the capital city of Jakarta, we have been coordinating with the Special capital city of Jakarta public order agency unit for preparation and selection of candidates for basic education and training for civil service police as many as 120 people in 4 batches in 2018 .

According to the document study, it was found that based on the results of the participant selection,Head of the Provincial Human Resources Development Agency for the special area of the capital city of Jakarta have assigned basic of Jakarta public order agency education and 
training, and summoning 120 civil service police education and training participants, through the letter number 2057/-084. 2. Dated march, 272019 addressed to the head of special capital city of Jakarta public order agency for revceiving direction from the Organizer and brings the profile of the Civil Service Police Education and Training Participant that has been updated from the Education Information System at www.simdiklat.bpsdm.jakarta.go.id

\section{2) Determination of Teaching Staff and Teaching Assistant}

Based on document studies, it was found that Head of the Provincial Human Resources Development Agency made letter of assignment to all the teachers, among other number 2888/0084-2, dated april, 262018 about Teachers of basic civil service police education and training for Civil Service Police Unit Staff in 2018 and letter of assignment number 1311/-084.2 dated February, 272018 about teaching assistent for basic civil service police education and training for civil service police unit staff in 2018 and letter number 388/084-2 dated January, 18 2018 terms of application for interviewees in Short pre-service Special Capital Territory of Jakarta public order agency training (diklatsar) and Letter of Assignment to the Assistance of Teaching Staff of 4 batches.

Whereas for teaching staff from outside the Provincial Human Resources Development Agency Special Capital Territory of Jakarta, a resource request letter is submitted through a letter from the Head of the special capital teritory of Jakarta Provincial Human Resources Development Agency.

3) Opening ceremony of the Special capital teritorry of Jakarta Province civil service police basic education and training program.

According to the inerview with Organizing Committee for education and basic training of civil service police, as is usual in organizing basic education and training program in the special capital city teritorry of Jakarta Provincial Government environment,Head of the special capital teritory of Jakarta Provincial Human Resources Development Agency inviting related local government leaders. Likewise, in the opening ceremony of the education and basic training of the provincial civil service police, the Special Capital Region of Jakarta in 2018.

Based on document studies it was found that the Head of the special capital teritory of Jakarta Provincial Human Resources Development Agency Submitting a brief letter to the civil service police trainees through the head of Jakarta public order agency with the letter number 1050/-084.12 dated February,20 2018 regarding Calls for short training and Invitation for Opening of education and training to: Head of Bina Marga Office, Head of Cipta Karya and Spatial Planning and Land, Head of Civil Service Police Unit, Head of Regional Financial Management Agency, Head of Regional Asset Management Agency, Head of Agency Regional Tax and Retribution, Structural Officials and Lecturers of the Jakarta Provincial Human Resources Development Agency.

\section{4) Committee Secretariat Services}

According to interview result with the Chairperson of the special capital territory of Jakarta Basic Education and Training Organizing Committee it stated that in an effort to support the success of the learning and teaching process, committe providing place and secretariat staff for giving data / information service, and monitoring accomodation and consumption service also the facilities service for the teaching staffs. Secretariat also giving trainingkit and and office stationery for the needs while attending basic education and training.

The results of observations to the venue at Jakarta Islamic Center, provided one room to be used as a place for the Committee's secretariat to provide education and basic training services for the Special capital territory of Jakarta public order agency.

5) Evaluation of Participant's Reaction to the implementation of the basic civil service police education and training program

For knowing the participant's response to the basic civil service police education and training program, according to interview result with the chairman of the committee it was stated 
that the reaction of participants in the basic civil service police training and education program was manifested in the form of participant evaluations of the organizers and facilities, and participant evaluation of teaching staff. Participant evaluations of the organizers and facilities, also participant evaluation of teaching staff showing good result. In line with the assessment, according to the results of the participants evaluation of the basic civil service police education and training program's teaching staff as shown in table 2 as follows :

Tabel 2

Participants evaluation of the basic civil service police education and training program's teaching staff

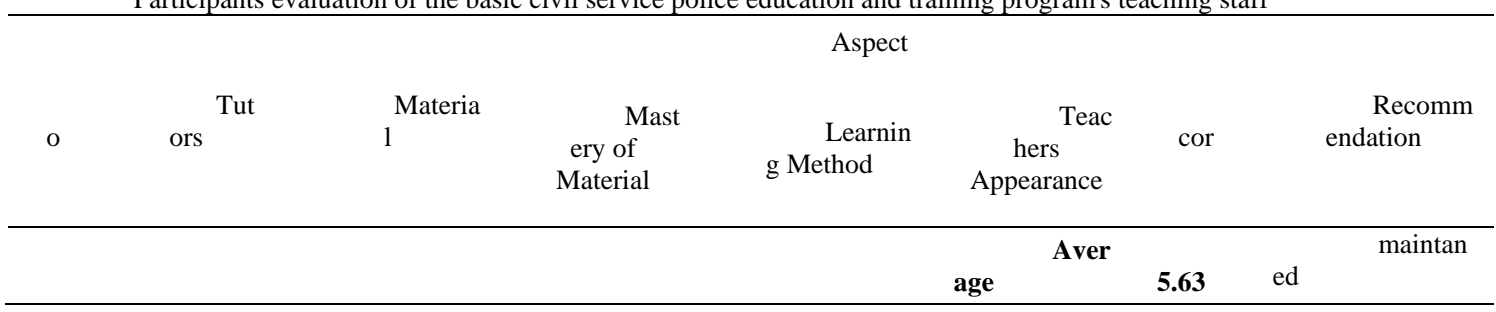

6) Evaluation of learning

Effectiveness training evaluation on second level Kirck Patrick Learning (learning) is accessing learning outcomes from the training conducted. Before and after the training. This methode is done simply by doing pre-test and post-test. The learning outcames obtained really needed but does not guarantee the application of knowledge obtained. According to document studies result information was obtained on evaluating the results of the participants of the Jakarta public order agency education and basic training program, as shown in table 3 as follows:

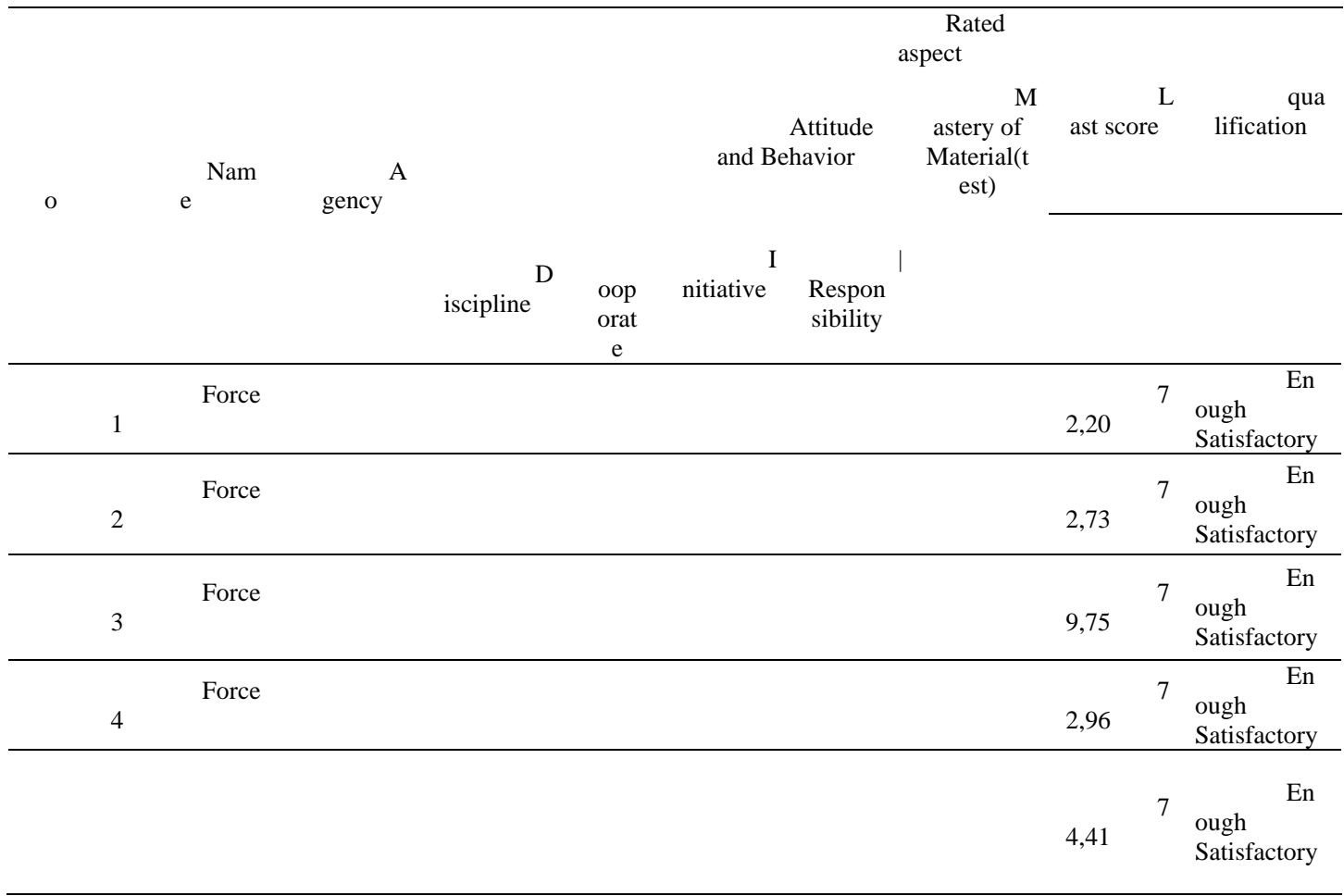

7) Evaluation of attitude

According to interview result with officials at the Civil Service Police Unit of the City Administration of West Jakarta and South Jakarta,measurement ohe alumni of the basic Jakarta public order agency education and training programs obtained result as shown in table 4 as follows 


\begin{tabular}{ccccccc}
\hline & City / District & Disci & \multicolumn{2}{c}{ Coorperat } & \multicolumn{2}{c}{ Responsi } \\
bility & Initiati & Beha \\
o & Administration & pline & 90 & 90 & 90 & 60 \\
\hline & West Jakarta & 90 & 90 & 90 & 70 \\
\hline & South Jakata & vior & 90 \\
\hline
\end{tabular}

From this finding, evaluation of basic Jakarta public order agency education and training program implementation process on aspect reaction evaluation, learning and attitude on 2012 until 2017 that be held by Jakarta public order agency unit cooperate with rindam jaya and Indonesian national police, achieve value $60 \%$, or in the enough category, that can interpeted that mostly done according to criteria, and furthermore evaluation results of civil service police education and training program implementation in 2018, which organized by Provincial Human Resources Development Agency specifically the capital city of Jakarta, reach 80\%, or in good category that can be interpreted, that mostly done according to criteria. Kirkpatrick (1998:20) states that "learning can be defined as the extend to which participans change attitudes, improving knowledge, and/or increase skill as a result of attending the program".

So that, training effectiveness, In this level, measured from the impact on participants. Is there any change after the training ends in knowledge aspect, skill, or work behavior to a better side, according to purpose of the training. Evaluation results of participants during the learning process, evaluation results of participant on organizer and teaching staff also evaluation result of the leader of civil service police unit from 2 administration city on alumni changes in behavior Of basic civil service police education and training program at workplace, achieve good grades.

\section{d. Product evaluation}

1) Outcomes of the basic civil service police education and training program

Findings of research / evaluation of basic civil service police education and training programs on product aspects conducted to a total of 120 participants of basic civil service police education and training in 2018, according to specified criteria, achieving the lowest value 70,10 and highest value 89,35 which means every participants passed well. Therefore average value reaches (test) mastery of knowledge : score 79.73 which mean good as many as 4 generations received a Good score satisfying, which means that most or all of them met the criteria. Achievement of competency in knowledge, skills and attitude of civil service behavior by showing that the program objectives

The evaluation results show that the application of the basic civil service police education and training program has been effective in achieving the objectives in the form of the achievement of competency mastery of knowledge, skills and attitude of civil servant behavior. Thus, the learning outcomes of achieving competency in knowledge, skills and attitude of civil servant behavior have increased so that they can be developed to achieve the targets set in the Medium-Term Regional Development Plan of the Province of the Special Capital Region of Jakarta. Jakarta.

2) Impact of basic civil service police education and training program

a) The findings in this research that the application of communication technique, negotiation and public control, and effective communication.

That knowledge application in enforcement of government regulations not showing optimal results or still less than expected. Therefore, education and training material need to be reviewed so that the time and case studies to understand and skillfully apply communication techniques in the enforcement of local regulations, are improved. Ability to socialize virtue and sanction also affirmation of certain zones that are prohibited from selling,is better given by the leader of local government agency that related in proposing regional regulations / regional head regulations, including the Small and Medium Enterprises Office, the Cipta Karya and City Planning Office, the Tourism Office, the Trade Office, and the Market Service and the Revenue Service. All leaders of the regional apparatus units should be scheduled to provide materials in basic civil service police education and training, both for implementing participants, supervisors and administrators. 
b) Increasing the volume and quality of the performance of the Special Capital Territory of Jakarta Public order agency unit.

The findings in this research, that the basic civil service police education and training program alumni performance in one of the Administrative Cities, it reaches a value of 80, which means good. This means basic civil service police education and training program alumni can develop knowledge and civil service police skills in workplace. Shove off from the condition, in the next time, to increase the performance of the civil service police unit, need to be done training, especially for alumni 1)basic education and training for civil service police who have held functional positions as civil service police so that the independent skills and work teams they have can produce the performance determined by their targets in the Provincial Medium Term Development Plan of the Jakarta Special Capital Region in 2018-2023.Beside, responze optimization through the public report that addressed to civil service police unit at https://www.lapor .go.id.

That works achievement results,shows there is a consistency of research results from Agus Sutiyono (2009) with the dissertation title Influence of Competency Based Education and Training or Competence Base Education And Training and work motivation in civil service police unit performance and Experimental studies on civil service police units, states that : $a$. The performance of Civil service police unit given the Competence Base Education and Training's training its better then the performance of civil service police unit given the conventional training.

c) Increase in revenue from regional retribution from the results of the performance of the police force

The findings in this research, is the civil service police through legal action violations, no plan of action or initiative from alumni has been developed. 1) The basic civil service police education and training for increasing the revenue from regional retribution. This condition describe that government regulation / head government regulation enforcement by civil service police unit and civil servant regional officials who in duty with increasing regional income and retribution are not yet synergistic.

The presence of civil service police officers, as if only on the conditions of the conflict problem, seems can be avoided with the specific program and budget in regional officials unit for doing guidance to community members including street vendors or people who violate building permits, understanding rules and prohibition,also sanction to be received if they are doing violation.

d) Reduction in accidents or victims of enforcement of regional regulations /head government regulation in an effort to create public order and public peace.

The findings on this research the absence of a strategic program for the civil service police unit for doing an anticipation on negative impact as a result of enforcement of government regulation/ head government regulation, especially in conflict-prone areas due to many violations of regional regulations / regional head regulations. This is different from the strategic program of civil service police in the city of Surabaya, as stated by the Mayor of Surabaya in the Workshop on the Application of Minimum Service Standards to the peace and public sub-sector organized by the Ministry of Home Affairs on 9 to 11 August 2017. Law enforcement in the city of Surabaya always Prioritize justice and humanists but remain firm. "There must be innovation and programs for humanist law enforcement. In field, those who are not right must be dealt with, but if they are right and need help, they must be helped, "said the Mayor of Surabaya. I

Not only firmly enforce regional regulations, civil service police in the city of Surabaya also doing another activities outside their duty as enforcement of regional regulation. She gave an example, when it rained civil service police also patrolled helping the car broke down and helped clean the sewers. Some innovations and programs done by the civil service police of Surabaya, making software program for government regulation enforcement like billboard monitoring, they also have segway,rollerblading to patrol the pedestrian and there is also a pink trail that is driven by a beautiful civil service police unit. 
An innovative strategic program for enforcing government regulationts/head government regulations that priotizing justice, humanists and reolute humanists, humble and firm, it could be encouraged to be compiled by each civil service police unit in the administration area of the Special Capital Region of Jakarta.

The materi in basic civil service police education and training also not accommodated related to risk management. Beside that connected with information technology era this time, the civil service police unit needs to be equipped with a monitoring room that can monitor through visual technology, the condition of certain areas that are the object of enforcement of local regulations / head regional regulations, so that before members are assigned to the field there are already several strategies owned to minimize the risk of conflicts or conflicts physical clashes between members of the civil service police and community members who violate regional regulations / head regional regulations.

\section{CONCLUSION AND RECOMMENDATION}

\section{Conclusion}

Based on evaluation program of basic Special capital region of Jakarta public order agency that has been explained above, conclusions obtained from the assessment results Good which can be interpreted that most have been carried out / available according to the criteria in the Context, Input, Process and Product stages of the basic education and training program of the Special capital region of Jakarta public order agency.

\section{Recommendation}

From thats results recommended for doing the development of basic Special capital region of Jakarta public order agency program by making improvement as follows:

In context evaluation stage, a) Improved the legal basis that became the program reference, which was originally law Number 32 of 2014 and government regulation number 6 of 2010 replaced by law number 23 of 2014 concerning Regional Government and Government Regulation Number 16 of 2018 concerning Civil Service Police so relevant to the noble policies of 2014 b) developing basic Special capital region of Jakarta public order agency program that integrated with Regional medium-term development plan that contains the vision and mission of the Governor of the Region 2018-2023 as well as targets and indicators in the field of public order and community peace and community protection, c) Developing basic education and training program objectives The Civil Service Police also organizes basic education and training programs for structural officials echelon 4, echelon 3 and echelon 2. And, d) Improving the quality of selection requirements for participants in the Civil Service Police education and training program base, in order to obtain prospective participants who have better academic and social skills and career experience and become exemplary examples in the Civil Service Police Unit where the relevant duty

In input evaluation stage, a) doing curriculum revition that giving a portion of material and time much more in case analysist and case simulation violatiance of government regulation/head government reguation, b) doing workshop about government regulation/head government regulation enforcement, which was attended by regional apparatus outside the civil service police unit including the ombudsman, also c) improving online education and training information system with new application, which is : Civil service police e-learning with material / modules prepared for education participants and Android-based technical and functional police training, accompanied by the preparation of Facilitators / Resource persons who can respond to questions and answers / discussions with civil service police e-learning participants.

In process evaluation stage, Following up the results of the evaluation of the participants of the organizers, facilities, curriculum, teaching staff during the education and training program, with the evaluation results from the Head of the Provincial and Municipal / District / 
Administrative Civil Service Police Unit and Subdistricts and Sub-Districts towards the alumni of the Civil Service Police education and training

In product evaluation stage, which includes outcomes and benefits, the Civil Service Police Unit formed an Evaluation Team for Achievement of targets and Indicators of problem solving Violations of Regional Regulations/Regulations of Regional Heads whose membership includes : Head of Provincial and City/Regency Administrative Civil Service Police Unit, Head of Market Service, Head of Small and Medium Enterprises Office, Head of Provincial Human Resources Development Agency for Jakarta Capital Special Region, Head of Legal Bureau, Head of Cipta Kartya and City Planning Office for Special Capital Region Jakarta and the Head of the DKI Jakarta Provincial Tourism Office, for doing evaluation also integrated achievements and problems faced in the enforcement of Regional Regulations / Regional Head Regulations as stipulated in the Provincial Medium-Term Regional Development Plan specifically for the capital city of Jakarta 2018-2023, and schedule regular meetings to analyze problems and find solutions and formulate recommendations for curriculum design input for educational programs and technical training and educational programs and training for functional positions in the Civil Service Police.

\section{REFERENCES}

Agus Sutiyono. 2009. The Effect of Competence Based Education and Training and Work Motivation on the Performance of Civil Service Police Officers Experimental Studies in Experimental Police Unit in the Jakarta Special Capital City Government.

Arikunto, Suharsimi and Cepi Safruddin Abdul Jabar.2014. Evaluation of Educational Programs: Practical Theoretical Guidelines for Students and Educational Practitioners. Second Edition. Jakarta: Earth Literacy.

Creswell, John W. 2017. Interpreting Ahmad Fahwaid. Research Design: Qualitative, Quantitative, and Mixed Approaches. Third Edition. Yogyakarta: Student Library.

Djaali and Pudji Muljono. 2008. Measurement in Education. Jakarta: Grasindo.

Kirkpatrick, Donald L. dan Kirkpatick, James D. 2005. Evaluating Trainning Program: The Four Levels. San Francisco: Berrett-koehler Publishers Inc.

Stufflebeam, Daniel L. and Chris L.S. Coryn. 2014. Evaluation: Theory, Models, \& Applicatons. Second Edition, San Fransisco-USA: Jossey-Bass, A Willey Brand.

Peraturan Menteri Dalam Negeri Nomor 38 Tahun 2010 tentang Pedoman Penyelenggaraan Pendidikan dan Pelatihan Dasar Polisi Pamong Praja.

Undang-Undang Nomor 23 Tahun 2014 tentang Pemerintahan Daerah.

Wirawan. Evaluation. 2011. Theory, Models, Standards, Applications, and Professions. Jakarta: Rajagrafindo Persada. 